\title{
Foucault e a arqueologia do impensado: paragens fenomenológicas
}

\author{
Foucault and the archeology of unthought \\ phenomenological stations
}

\section{Claudinei Aparecido de Freitas da Silva*}

Universidade Estadual do Oeste do Paraná (UNIOESTE), Toledo, PR, Brasil

\section{Resumo}

Foucault inscreve a fenomenologia num movimento de desconstrução da racionalidade. Esse registro será arqueologicamente operado em As Palavras e as Coisas como signo de uma subversão radical vinda a lume pela "modernidade" em franca oposição à "idade clássica" da cultura no Ocidente, tendo como pano de fundo algo que se revela aquém do cogito: o "impensado". O que emerge, aqui, é a dimensão mais profunda da razão e da epistémê, ou seja, a camada subterrânea pela qual o acontecimento e a historicidade operam sob a superfície do saber. É essa nova figura que entra em cena, por exemplo, via diferentes discursos como a "alienação" (marxismo), o"inconsciente" (psicanálise) ou o "irrefletido" (fenomenologia). No tocante à tradição fenomenológica, a admissão da Lebenswelt (Husserl),

* CAFS: Pós doutor, e-mail: cafsilva@uol.com.br 
do Dasein (Heidegger), do cogito pré-reflexivo (Sartre) ou da Carne (Merleau-Ponty), o “impensado" transfigura a região privilegiada pela qual o pensamento sempre retorna. Ora, se é patente que Foucault circunscreve essa operação como uma posição de princípio a ser superada, não deixa, contudo, de ser plausível o quanto ele parece selar uma espécie de "aliança à distância" com o espírito fenomenológico. O "retorno às coisas mesmas", em termos foucaultianos, investe-se de outro estatuto, liberando a história de todo pressuposto teleológico, num regresso ao coração do presente. É esse agenciamento que permite, sob certos aspectos, situar a obra de Foucault próxima a de Merleau-Ponty, à maneira de uma reflexão marginal, "transgressora", abrindo, pois, uma zona de sombra, "impensada", em sua infraestrutura última. Tal é a "paragem" interpretativa a ser, aqui, perseguida.

Palavras-chave: Foucault. Arqueologia. Impensado. Cogito. Modernidade.

\section{Abstract}

Foucault inscribes the phenomenology in a movement of deconstruction of the rationality. This registration will be operated archaeologically in The Order of Things as a sign of a radical subversion coming to light by "modernity" in frank opposition to "classical age" culture in the Occident, having as a background something that is revealed beneath the cogito: the "unthought". What emerges here is the deepest dimension of reason and epistémê, ie, the subterranean layer in which the event and the historicity operate under the surface of knowledge. It is this new figure enters the scene, for example, in different discourses as "alienation" (marxism), "unconscious" (psychoanalysis) or "unreflective" (phenomenology). Concerning the phenomenological tradition, the admission of Lebenswelt (Husserl), the Dasein (Heidegger), the pre-reflexive cogito (Sartre) or Flesh (Merleau-Ponty), the "unthought" transfigures the privileged region in which the thought always returns. While it is patent that Foucault circumscribes this operation as a position of principle to be surpassed, not leave, however, to be plausible how much he seems to seal a sort of "alliance distance" with the phenomenological spirit. The "return to the things themselves", in Foucault's terms, investing is another statute, releasing the history of all teleological premise, as a return to the heart of the present. It is this It is this task that allows, in some respects, situate the work of Foucault next to MerleauPonty, in the style of a marginal reflection, "transgressor", opening therefore a shadow zone, "unthought" in his last infrastructure. Such is the interpretive "station" to be here pursued.

Keywords: Foucault. Archeology. Unthought. Cogito. Modernity. 
"O homem ... produz impensadamente"

(PANZERI, 2011, p. 30)

A Boris Schnaiderman,

In memoriam

\section{Introdução}

Uma Arqueologia das Ciências Humanas. É com esse subtítulo que, há 50 anos, Foucault daria vazão As Palavras e as Coisas como uma obra intrepidamente capital no intuito de se situar dois registros da epistémê na cultura do Ocidente: a "idade clássica" que culmina no século XVIII e o limiar de um novo período: a "modernidade" que toma curso, sobretudo, a partir do século XIX. O que teria provocado tal descontinuidade na ratio europeia a ponto de a teoria da representação soçobrar-se ante certo trabalho "anarcôntico"1 ${ }^{1}$ quanto a seus fundamentos últimos?

"Uma historicidade profunda penetra no coração das coisas", prefigura, logo de saída, Foucault (FOUCAULT, 1966, p. 140). “Na medida, porém" - prossegue ele - "em que as coisas giram sobre si mesmas, requerendo para seu devir não mais que o princípio de sua inteligibilidade e abandonando o espaço da representação, o homem, por seu turno, entra, e pela primeira vez, no campo do saber ocidental" (Idem, 1966, p. 14-15). Esse "homem", estranhamente, abre "certa brecha na ordem das coisas" (Idem, 1966, p. 15). Não passando de "uma simples dobra de nosso saber" (Idem, 1966, p. 15), esse distinto personagem ainda é uma "invenção recente", haja vista que não conta com mais de dois séculos. O que entra em jogo, nesse momento, é uma nova forma de "experimentar certa proximidade com as coisas" (Idem, 1966, p. 15).

1 Termo oriundo de "arconte" (do grego, apxwv, (arkhon), referente ao sentido de arkhê: (arco + centro). É, por exemplo, Husserl que descreve a esfera do vivido intencional, reportando-se à sua essência ou fundação concreta dotada de um "caráter posicional". Trata-se, diz ele, de "uma tese 'arcôntica', que unifica em si e rege todas as outras" (HUSSERL, 2006, $\S 117$, p. 262). Bento Prado Jr (1976, p. 173) toma a expressão sugerindo a ideia de que a modernidade empreende uma operação crítica de demolição de fundamentos arraigados pela tradição metafísica. 0 trabalho "anarcôntico" é aquele que refaz certo movimento regressivo, levando-nos do fato às suas condições formais ou transcendentais. 
Algo de subhumano aí se desvela: a mais radical e abissal espessura do homem como dimensão originariamente inalienável. Como então situar essa "descoberta nova", ou melhor, compreender tal passagem no limiar de nossa modernidade? Aos olhos de Foucault tal tarefa exige um procedimento sui generis: o de um trabalho arqueológico.

\section{Arqueologia}

Visando reconstituir as condições históricas de possibilidade do saber, a arqueologia acompanha um movimento descontínuo da razão. Trata-se de abrir fendas, brechas, dobras, rupturas, quer dizer, agenciar uma maneira de ser e compreender mecanismos capazes de articular diferentes discursos. É nessa perspectiva que Foucault começa por situar um esquema reflexivo de longa data: seja no âmbito metafísico, político ou científico, vige a ideia de que o homem e a natureza tomam como princípio ordenador uma fundação arquimédica, cuja expressão paradigmática, é o cogito cartesiano. O mundo "reduz-se a um ponto, a uma massa homogênea, à morna figura do Mesmo" (FOUCAULT, 1966, p. 39). O ideal de similitude torna-se, portanto, um cânon a ser perseguido: ele se cristaliza como um modelo corolário do pensamento clássico, isto é, um paradigma que orienta a consciência europeia até o século XVIII.

Fato é que essa cosmovisão vai, cada vez mais, perdendo seu firmamento, seu poder de transparência. Não há mais base sólida, porto seguro, refúgio absoluto. $O$ solo cartesiano que até então acreditava-se firmemente apoiar-se se estremece por completo: ele sofre uma erosão sem limites. É o que passa ocorrer, na passagem de século, quando, no limite, descobre-se, o quanto a razão é recoberta por uma zona de obscuridade inextinguível, mas essencial, vital. O homem que passa habitar a partir do século XIX é aquele tomado por uma "revelação subterrânea" (Idem, 1966, p. 51)²: ele se vê, agora, em sua mais visceral

2 Dois "arquivos" podem ser aqui reportados em plena literatura do século XIX: a metáfora do "subsolo", cujas memórias põe 0 homem diante do paradoxo inalienável da consciência, em Dostoiévscki (2000), e os Les misérables (1993), de Victor Hugo. 
e trágica condição errante, miserável como nômade. Este é o "homem recente" que passa a existir, de fato e de direito.

O que, afinal, a modernidade escava? Mais abaixo da cultura, uma "dimensão absolutamente aberta" inscreve Foucault (Idem, 1966, p. 56). É sob esse ângulo que a "alienação" em Marx, o "inconsciente" freudiano ou a Lebenswelt husserliana ${ }^{3}$ tornam-se transfigurações discursivas desse páthos ou novo domínio presuntivo da ratio, da epistémê a ponto até mesmo de levantar a suspeita se o discurso filosófico não ter-se-ia afundado no pântano do irracionalismo. Não se trata de sacrificar a Razão, anulando-a em nome de qualquer irracionalismo, mas, sim, de salvaguardá-la ${ }^{4}$. É o que assegurará Merleau-Ponty (Idem, 1966, p. 79) inspirando-se em Hegel, ao se reportar à ideia de uma "razão alargada" (raison élargie) tendo, como referência emblemática, a obra de Lévi-Strauss:

O antropólogo não é somente um etnólogo. Essa comunicação que obteve com populações arcaicas, ele quer pensá-la, explicá-la [...]. Essa análise ligava costumes aparentemente irracionais à mesma função que fundamenta entre nós a racionalidade, e cumpria assim a promessa da Antropologia Social, que é abrir um campo comum às culturas, ampliar nossa razão reconduzindo-a as suas fontes e torná-la assim capaz de compreender o que não é ela (MERLEAU-PONTY, 2009, p. 218, grifo nosso).

Nessa direção, mais que adotar um simples método etnológico, Lévi-Strauss ensaia uma maneira especial de compreender, falar, viver. Trata-se de outro modo de acercar sua pesquisa, "alargando racionalmente" um olhar que não toma distância de seu objeto, mas que o compreende sob uma estrutura mínima de relações. A arqueologia lévi-straussiana escava, portanto, uma camada mais abaixo, originariamente selvagem, instituindo um terreno comum em que eu e outrem possam interagir, sem qualquer sobreposição hierárquica.

3 Ver, p. ex., HUSSERL (2008); CASTILHO (2015) e SILVA (2012).

4 Como atenta Bento Prado Jr (2004, p. 256): "Irracionalismo é um pseudoconceito. Pertence mais à linguagem da injúria do que da análise. Que conteúdo poderia ter, sem uma prévia definição da Razão?". 
Foucault mostra que essa reviravolta se opera no momento em que ao sair do quadro da representação e da mathesis, uma nova forma de experiência do saber toma curso. Nessa medida, o que na ordem clássica, se ditava pela análise da representação, agora, no período moderno, responde pela análise do sentido e da significação. Trata-se de "percorrer o acontecimento em sua disposição manifesta" (FOUCAULT, 1966, p. 230). "Sem dúvida", julga ele (Idem, 1966, p. 232), "porque estamos ainda presos em sua abertura, há um acontecimento que, em grande parte, nos escapa". A constituição de várias ciências positivas (sociologia, etnologia, psicologia, literatura) imprime esse alargamento de horizonte. $\mathrm{O}$ que tais saberes abrem é o acesso às várias camadas profundas, revelando, por fim, um "acontecimento subterrâneo" (Idem, 1966, p. 251); evento esse que expõe, a nu, "as rugas traçadas pela primeira vez sobre a face esclarecida do saber" (Idem, 1966, p. 251). O que se desbrava é um "mundo-subjacente, mais profundo que ela própria (a representação) e mais espesso" (Idem, 1966, p. 252). É do fundo dessa força que o acontecimento não cessa de se produzir como historicidade, abalando, de maneira inédita, o pensamento ocidental. Daí segue-se o indiscreto elogio a Kant, uma vez que a Crítica interroga a representação para além do seu habitual espaço canônico em que, por séculos afora, estivera confinada. Se a Crítica marca o limiar de nossa modernidade é porque traz à tona uma dimensão nova, "pondo a descoberto um campo transcendental em que o sujeito, que jamais é dado à experiência (pois não é empírico), mas que é finito [...] determina na sua relação com um objeto $=x$ todas as condições formais da experiência em geral" (Idem, 1966, p. 256). A Crítica teria começado a escavar certo solo arqueológico fazendo-nos "reconhecer o traço desse acontecimento profundo que, por volta do fim do século XVIII, apartou do espaço das representações a possibilidade da síntese" (Idem, 1966, p. 259). Pois bem: é "essa região onde se funda toda experiência" (Idem, 1966, p. 260) que se torna a destinação mais própria do pensamento moderno.

Assim, a cultura europeia inventa para si uma profundidade em que a questão não será mais a das identidades, dos caracteres distintivos, 
dos quadros permanentes com todos os seus caminhos e percursos possíveis, mas a das grandes forças ocultas desenvolvidas a partir de seu núcleo primitivo e inacessível; mas, ainda, a da origem, da causalidade e da história. Doravante, as coisas só virão à representação do fundo dessa espessura recolhida em si, emaranhadas talvez e tornadas mais sombrias por sua obscuridade (FOUCAULT, 1966, p. 263-264).

O que, ao fim e ao cabo, mudara na curva do século? O reconhecimento, ao nível arqueológico, de camadas, espessuras. E isso quer no âmbito da economia (Ricardo, Marx), quer na crítica dos valores (Nietzsche), quer na psicanálise (Freud) e na biologia (Goldstein). É uma nova verdade antropológica que recebe outro estatuto: a finitude inalienavelmente humana. Desse modo, se na época clássica, a natureza era contínua, sem lacuna, nem falhas, formando um conjunto homogêneo, no período moderno, o que se descortina é outro cenário: a "dimensão que escapa ao percebido" (FOUCAULT, 1966, p. 280). A natureza aparece como que descontínua, enigmática no sentido de que “o ser vivo, a partir de Cuvier, escapa, ao menos em primeira instância, às leis gerais do ser extenso" (FOUCAULT, 1966, p. 286). Não há mais continuidade entre o ser e a natureza:

Há como uma devoração perpétua da vida por ela mesma. Ela só pertence à natureza quando encerra em si um núcleo de contranatureza. Transferindo sua mais secreta essência do vegetal ao animal, a vida abandona o espaço da ordem e volta a ser selvagem. Revela-se mortífera nesse mesmo movimento que a vota à morte. Ela mata porque vive. A natureza já não sabe mais ser boa [...]. Assim, talvez, pela primeira vez na cultura ocidental, a vida escapa às leis gerais do ser, tal como ele se dá e se analisa na representação [...]. A vida tem um valor radical no pensamento do século XIX, ela é, ao mesmo tempo, núcleo do ser e do não-ser: Só há ser porque há vida (FOUCAULT, 1966, p. 290; 290-291) 5 .

É esse pensamento "reacionário" de cariz cuvieriano que adentra uma "profundidade arqueológica e não ao nível mais aparente

5 Ver, a propósito, Whitehead (2004), Merleau-Ponty (1995) e Silva (2010). 
das descobertas, das discussões, teorias, ou das opções filosóficas" (FOUCAULT, 1966, p. 287). Para além do velho fixismo, da ordem rochosa de um fundamento inabalável, emerge um fundo não entrevisto: a historicidade do saber, ou seja, a um "modo de ser profundamente histórico das coisas e dos homens" (Idem, 1966, p. 289). É a descoberta dessa "historicidade viva" (Idem, 1966, p. 289) que inscreve, arqueologicamente, no calendário da modernidade, uma agenda permanente.

Adentremos um pouco mais nesse domínio permanecido, por princípio, "impensado".

\section{Impensado}

Até aqui, Foucault nos mostrara que a cultura ocidental a partir da modernidade toma uma nova consciência de seu tempo; consciência que dirige outro olhar sobre o mundo, os seres vivos, o próprio homem. Por isso, o filósofo lança mão da ideia de historicidade com o intuito de demarcar, ali, certo nível de experiência mais radical: o acontecimento. Esse vem à tona, como retrata ele, via uma "transmutação arqueológica" no sentido de um incansável trabalho de escavar as "camadas subterrâneas" da razão e da epistémê. A exemplo da antropologia e da biologia, a linguística também se insere nesse movimento iconoclasta, "anarcôntico" em que a linguagem é apreendida em seu devir próprio, uma vez que os verbos não designam coisas simplesmente, mas ações, processos, vontades. A linguagem não imita ou reduplica as coisas, mas torna manifesto o desejo fundamental de quem fala. É o que realiza Saussure, "ao contornar esse momento da fala, que foi capital para toda a filologia do século XIX, a fim de restaurar, para além, das formas históricas, a dimensão da língua em geral" (FOUCAULT, 1966, p. 299). Ora,

[...] as condições de historicidade da linguagem são modificadas; as mutações não vêm mais do alto (da elite dos sábios ...), mas nascem obscuramente de baixo, pois a linguagem não é mais um instrumento, 
ou um produto - um ergon, como dizia Humboldt - mas uma incessante atividade - uma energeïa (FOUCAULT, 1966, p. 303).

Nessa escalada, se o saber clássico era canonicamente nominalista, no momento inaugural da modernidade, "a linguagem se dobra sobre si mesma, adquirindo sua espessura própria, desenvolvendo uma história, leis e uma objetividade que só a ela pertencem" (FOUCAULT, 1966, p. 309). Essa historicidade viva que permeia os seres e que se introduz sub-repticiamente na experiência da língua, não é uma ficção; ela é um "acontecimento arqueológico", atesta Foucault (Idem, 1966, p. 307). É esse alcance que a experiência moderna visa, dilacerando, de um só golpe, o coração da representação, fazendo existir o que até o fim da idade clássica não existia: o homem enraizado na vida, no trabalho e na linguagem. A modernidade aviva tal consciência epistemológica. Confere-lhe, como registra Foucault, um estatuto mais estável. É por meio dessa torção interna que vem à tona a espessura subjacente inalienável do humano: sua finitude; esta "marcada pela espacialidade do corpo, pela abertura do desejo e pelo tempo da linguagem" (Idem, 1966, p. 326). Cabe ainda observar que a analítica da finitude opera em outro registro: ela não se deduz mais desde um pensamento infinito, mas, antes, nasce, do ventre do concreto; é embebida na contingência. Nessa extensão, "de um extremo ao outro da experiência, a finitude responde a si mesma; ela é, na figura do Mesmo, a identidade e a diferença das positividades e de seu fundamento" (Idem, 1966, p. 326). Por isso, sem maiores cerimônias, Foucault se reportará a tal evento, realmente único na história, sob a figura da descoberta de um "duplo empírico-transcendental” (Idem, 1966, p. 330). Será esse o destino do pensamento moderno cujo campo transcendental se altera radicalmente, ou seja, há o advento de um "novo homem" reconhecido em sua mais paradoxal "duplicidade, impensável, pois, no humanismo clássico. É assim que a analítica da finitude implicaria, ainda, outra análise: a do vivido. Trata-se "do espaço onde todos os conteúdos empíricos são dados à experiência; como a forma originária que os torna, em geral, possíveis e designa seu enraizamento primeiro" (Idem, 1966, p. 332). É a análise do vivido que "restaura a dimensão esquecida do transcendental" (Idem, 
1966, p. 332). É nessa confluência que o "impensado" aflora nos limites últimos do cogito.

A fim de melhor descrever esse "afloramento", Foucault consagra, no tópico V do capítulo 9 de As Palavras e as Coisas, o breve texto "O cogito e o impensado". Modernamente falando, "o homem não se pode mais dar na transparência imediata e soberana de um cogito" (Idem, 1966, p. 333). Há, então, o reconhecimento de que "o homem é um modo de ser tal que nele se funda esta dimensão sempre aberta, jamais delimitada de uma vez por todas, mas indefinidamente percorrida" (Idem, 1966, p. 333). Isso ocorre porque ele se projeta em "todo horizonte silencioso do que se dá na extensão movediça do não-pensamento" (Idem, 1966, p. 333). Assim,

Porque é duplo empírico-transcendental, o homem é também o lugar do desconhecimento [...]. É essa a razão pela qual a reflexão transcendental, sob sua forma moderna, não mais encontra o ponto de sua necessidade, como em Kant, na existência de uma ciência da natureza [...], mas na existência muda [...] desse não-conhecido a partir do qual o homem é incessantemente chamado ao conhecimento de si (FOUCAULT, 1966, p. 333-334).

A indefinibilidade do homem como signo de seu próprio desconhecimento só se dá em virtude da recém descoberta de uma estrutura infranqueável quanto ao modo de ser do homem, não sendo de sua natureza ou essência. Tudo perpassa como se encontrássemos uma unidade gestáltica entre a razão e a desrazão: uma é figura; a outra é fundo. O que a modernidade escava? Precisamente, esse "fundo" desconhecido, o subsolo mesmo do pensamento, essa camada que teria permanecido inexplorada, intacta, aquém do conceito homem ${ }^{6}$. Tratase de uma "existência muda", clandestinamente vivida pelo homem. É ela que comanda o trabalho da reflexão ou do conceito, mergulhando, doravante, a luz cartesiana em sua mais tácita e sombria condição. É nessa medida que o deslocamento do argumento transcendental

6 Como nota Lebrun (2006, p. 342), "0 classicismo não teria chegado a reconhecer essa alienação constitutiva, inextirpável", pela analítica moderna da finitude. 
reativa o tema do cogito, operando-o numa direção arqueológica. Uma dimensão mais profunda na cultura moderna emerge: o enraizamento no não-pensado. Como explica Foucault (Idem, 1966, p. 335): cumpre "percorrer, reduplicar e reativar, sob uma forma explícita, a articulação do pensamento com o que nele, em torno dele, debaixo dele, não é pensamento, mas que, nem por isso, lhe é estranho". Tais palavras remetem-nos ao ponto nevrálgico de seu diagnóstico: o que esse cogito moderno desvenda não é mais, em sentido clássico, algum poder incomparável de evidência, mas uma "interrogação sempre recomeçada" (Idem, 1966, p. 335). Quer dizer: "ele não reconduz todo o ser das coisas ao pensamento sem ramificar o ser do pensamento até na nervura inerte do que não pensa" (Idem, 1966, p. 335).

Há sempre - reitera Foucault - algo que, de forma sub-reptícia, perpassa a reflexão, o cogito, a linguagem, o trabalho, a vida. É nisso que, essencialmente, consiste a tarefa arqueológica: explorar a camada originária pela qual cada um desses níveis perpassados se articulam. Afinal, por que Freud é um ícone dos tempos modernos? Porque

De fato, o inconsciente e, de maneira geral, as formas do impensado, não foram a recompensa oferecida a um saber positivo do homem. O homem e o impensado são, ao nível arqueológico, contemporâneos. O homem não pôde desenhar-se como uma configuração na epistémê, sem que o pensamento simultaneamente descobrisse, ao mesmo tempo em si e fora de si, nas suas margens, mas igualmente entrecruzados com sua própria trama, uma parte de noite, uma espessura aparentemente inerte em que ele está engajado, um impensado que ele contém de ponta a ponta, mas em que do mesmo modo se acha preso. O impensado (qualquer que seja o nome que se lhe dê) não está alojado no homem como uma natureza encarquilhada ou uma história que nele se houvesse estratificado, mas é, em relação ao homem, o Outro: o Outro, fraterno e gêmeo, nascido não dele, nem nele, mas ao lado e ao mesmo tempo, numa idêntica novidade, numa dualidade sem apelo (FOUCAULT, 1966, p. 337).

O impensado freudiano (no caso, aqui, o inconsciente) é uma alteridade inalienável, portanto, "fraterna", "gêmea", "noturna" da razão. Essa trama entre o humano e as formas do impensado revela bem o movimento arqueológico que tanto Foucault tem em vista. 
Merleau-Ponty, por sua vez, lê Freud, nesses termos (FOUCAULT, 2000, p. 282-283):

[...] ao menos as metáforas energéticas ou mecanicistas guardam contra toda idealização o selo de uma intuição que é uma das mais preciosas do freudismo: a de nossa arqueologia [...]. Trata-se de aprender ler Freud como se lê um clássico, isto é, tomando as palavras e os conceitos teóricos dos quais ele se serve não em seu sentido lexical e comum, mas segundo o sentido que adquirem no interior da experiência que anunciam.

É nesse sentido que o inconsciente é essa "região fundamental", não-pensada que não só Freud (2010), mas a própria etnologia entrevira, cada vez mais, como "duplo insistente", isto é, como o Outro, a sombra de fundo desde onde o Mesmo se projeta.

A psicanálise e a etnologia ocupam, no nosso saber, um lugar privilegiado. Não certamente porque teriam, melhor que qualquer outra ciência humana, embasado sua positividade e realizado enfim o velho projeto de serem verdadeiramente científicas; antes porque, nos confins de todos os conhecimentos sobre o homem, elas formam seguramente um tesouro inesgotável de experiências e de conceitos, mas, sobretudo, um perpétuo princípio de inquietude, de questionamento, de crítica e de contestação daquilo que, por outro lado, pôde parecer adquirido. (FOUCAULT, 1966, p. 385).

Por isso, pode escrever Foucault (1966, p. 338): “todo o pensamento moderno é atravessado pela lei de pensar o impensado [...]; de levantar o véu do Inconsciente, de absorver-se no seu silêncio ou de pôr-se à escuta de seu murmúrio indefinido" ${ }^{\prime 7}$. Nessa investida, se "não pode descobrir o impensado, ou ao menos ir em sua direção, sem logo aproximá-lo de si" (Idem, 1966, p. 338) é porque há um vínculo gêmeo, contemporâneo entre o homem e sua dimensão inalienável. É isso que torna o pensamento moderno um "certo modo de ação" (Idem,

7 Ilustra Canguilhem (2012, p. 29): "Mas pensar o impensado não é apenas, segundo Foucault, pensar no sentido teórico ou especulativo deste termo, é produzir-se correndo o risco de espantar-se e até de aterrorizar-se consigo mesmo", já que 0 pensamento é, em si próprio, uma ação, um ato perigoso. “Estamos, aqui, diante de um explorador e não de um missionário da cultura moderna" (Idem, op. cit., p. 13). 
1966, p. 339) a ponto de esculpir outra fisionomia do humano em várias frentes ou matizes. Esse homem que, por ora, se "descobre ligado a uma historicidade já feita" (Idem, 1966, p. 341) é quem jamais se esquiva de seu Outro que permanentemente o margina por estar mais próximo dele. É nessa "imensa região de sombra onde o trabalho, a vida e a linguagem ocultam sua verdade [...] que o originário, no homem, é aquilo que, desde o início, o articula com outra coisa que não ele próprio" (Idem, 1966, p. 342). É nessa perspectiva mais ampla que se torna plausível reconhecer "a relação perpétua do cogito com o impensado" (Idem, 1966, p. 346). A "arqueologia do impensado" figura, nesse cenário de abertura, de frequentação, de práxis. Talvez seja aí, indica Foucault (Idem, 1966, p. 350), que "se enraíza a mais importante opção filosófica de nossa época"; opção, intrepidamente assumida em meio à finitude radical, à ambiguidade essencial que, a um nível mais profundo (arqueológico) revela no homem sua historicidade na lógica do acontecimento. Com isso, "se tece sob nossos olhos o destino do homem, mas tece-se às avessas; nesses estranhos fusos, é ele reconduzido às formas de seu nascimento, à pátria que o tornou possível" (Idem, 1966, p. 393). O impensado emerge, enfim, nesse plano, como o avesso arqueológico, por excelência.

O ponto chave é que, nesse duplo movimento (empírico-transcendental), arquiva Foucault, "instaura-se uma forma de reflexão, bastante afastada do cartesianismo e da análise kantiana, em que está em questão, pela primeira vez, o ser do homem, nessa dimensão segundo a qual o pensamento se dirige ao impensado e com ele se articula" (Idem, 1966, p. 336). Ora, é nisso que se compreende melhor a tarefa da fenomenologia:

A fenomenologia é, portanto, muito menos a retomada de uma velha destinação racional do Ocidente, que a constata, bem sensível e ajustada, da grande ruptura que se produziu na epistémê moderna, na curva do século XVIII para o século XIX. Se a alguma coisa está ligada é a descoberta da vida, do trabalho e da linguagem; é também a essa figura nova que, sob o velho nome de homem, surgiu não há ainda dois séculos; é à interrogação sobre o modo de ser do homem e sobre sua relação com o impensado. É por isso que a fenomenologia - ainda que se tenha esboçado primeiramente através do antipsicologismo, ou, antes, na 
medida mesma em que, contra este, tenha feito ressurgir o problema do a priori e o motivo transcendental - jamais pôde conjurar o insidioso parentesco, a vizinhança ao mesmo tempo prometedora e ameaçante com as análises empíricas sobre o homem; é por isso também que, embora se tenha inaugurado por uma redução ao cogito, ela foi sempre conduzida a questões, à questão ontológica. Sob nossos olhos, o projeto fenomenológico não cessa de se resolver numa descrição do vivido que, queira ou não, é empírica, e uma ontologia do impensado que põe fora de circuito a primazia do "Eu penso" (FOUCAULT, 1966, p. 336-337).

Foucault, nessas linhas, é categórico quanto ao papel desempenhado pela análise fenomenológica: a "descrição do vivido" e a "ontologia do impensado" constituem o âmbito pelo qual se sela mais uma ruptura no interior da epistémê moderna. Nesse intento, não se trata de problematizar como Lebrun (1989) se os fenomenólogos bem ou mal leram os clássicos ou se fizeram as devidas honras ou não a Kant ${ }^{8}$. O que, de fato, importa, é o mapeamento (cartográfico) operado por Foucault acerca do projeto fenomenológico, ou seja, até que ponto tal movimento avivara essa dimensão que, a todo tempo, teria escapado aos tentáculos do cogito, mas que, intimamente a este se articula?

\section{0“impensado" fenomenológico}

Sabe-se que a região do impensado fora o tema de fundo em que se inscreve O Filósofo e sua Sombra, texto em que Merleau-Ponty vislumbra certo horizonte de pesquisa aberto por Husserl:

Quando Husserl termina sua vida, há um impensado de Husserl que pertence realmente a ele e, no entanto, abre para outra coisa. Pensar não é possuir objetos de pensamento; é circunscrever através deles um domínio para pensar que, portanto, ainda não foi pensado [...]; assim também,

8 Lebrun (1989) enfatiza de que As Palavras e as Coisas operariam como uma espécie de anti-Krisis, a propósito da leitura husserliana de Kant em a Crise das Ciências Europeias (2008). 
a obra e o pensamento de um filósofo são feitos de certas articulações entre as coisas ditas. (MERLEAU-PONTY, 1960, p. 202; grifo nosso) ${ }^{9}$.

Em termos husserlianos, assinala Merleau-Ponty, o impensado é essa inflexão da razão, isto é, uma zona de evidência pré-teorética; a terceira dimensão aquém do "objetivo" e do "subjetivo" que se articula com o próprio trabalho de reflexão. Ao descer ao campo de nossa arqueologia, Husserl escava um "impensado por pensar". Ou como retrata Chauí (2002, p. 39; 40):

O impensado não é o que não foi pensado, nem o que tendo sido pensado não soube ser dito, nem muito menos o que teria sido pensado e não pôde ser proferido. Não é o 'menos'; é o excesso do que se quer dizer e pensar sobre o que se diz e se pensa [...]. O impensado não é o que estaria ausente como privação, mas aquilo cuja ausência é promessa e antecipação. Como todo invisível, o impensado é uma ausência que conta no mundo porque não é um vazio, mas ponto de passagem. Não é buraco. É poro. Não é lacuna que preenchemos, mas trilha que seguimos.

É sob esse prisma que as relações entre Foucault e a fenomenologia pode ganhar novos contornos, a despeito de suas diferenças. Lebrun (1989, p. 44), inclusive, credita que "Foucault salvaguarda a coerência da fenomenologia", uma vez que, no tocante As Palavras e as Coisas, indaga-se o intérprete:

Qual pode ser, uma vez terminado o livro, a visão da fenomenologia que se comunica ao leitor? É a visão de uma filosofia de duas vertentes. Na primeira vertente, mais clara, se trata de um pensamento que se interessa integrar com o seu tempo a fim de encontrar a necessidade que o regia [...]. A segunda vertente, é o que fica da imagem tradicional que se conservou de Husserl (a epoqué, o idealismo). Isso a arqueologia parece deixar à sombra (LEBRUN, 1989, p. 45, grifo do autor).

9 É 0 que assenta também Heidegger (1997, p. 105): “Tratando-se do pensar, quanto maior for a obra feita - 0 que absolutamente não coincide com a extensão e a quantidade dos escritos - mais rico, será nessa obra, o impensado, ou seja, aquilo que, através dela e somente por ela, volta-se para nós como 0 ainda jamais pensado". 
Seja como for, Lebrun (1989, p. 48) rememora: “haveríamos de esquecer que o 'a priori histórico' é uma expressão de origem husserliana bem como a atração que exercia, em Husserl, a palavra arqueologia?". Micieli (2003, p. 143) ainda vais mais longe:

Apesar do antagonismo explícito entre Foucault e Husserl, não se corrobora que a teoria arqueológica seja capaz de superar as dificuldades da fenomenologia, quer dizer, não se prova que a dessubjetivação do saber seja suficiente para escapar à ambivalência que se imputa ao projeto fenomenológico. Ora, como não se sentir impressionado pela similaridade que há entre a redução fenomenológica e a posição de independência e neutralidade que adota o arqueólogo?

Talvez Foucault apareça, nesse cenário, como "o último fenomenólogo" (DREYFUS; RABINOW, 1995, p. 58), isto é, como aquele que oferece uma "fenomenologia" visando, implacavelmente, pôr fim a própria fenomenologia. O que por si só indicia, mostra Nalli (2006, p. 200), de que "havia bem mais do que mera afinidade retórica entre a arqueologia e a fenomenologia". Afinal, se não deixa de ser um grave equívoco reduzir a obra de Foucault a uma arqueologia haja vista que esta última fora, tão somente, um dos métodos de que se valeu ou ainda de que a arqueologia não dá a chave de seu projeto, é porque ela, ao menos, nota Lebrun (HUSSERL, 2006, p. 352) tornou-se um momento necessário enquanto "transgressão da finitude". Em função disso, se, para Foucault, "não há nada prévio ao saber", nem tampouco qualquer "experiência originária" (MICIELI, 2003, p. 135) do gênero, seria preciso, contudo, examinar até onde esse programa arqueológico não encerra num limite:

Mas se não podemos pensar a finitude nem desde um ser infinito (Deus) nem a partir da finitude do homem (do Dasein, por exemplo), então desde que lugar é possível pensar o discurso filosófico? A falta de resposta na obra de Foucault à questão filosoficamente mais relevante impede de construir uma teoria geral da arqueologia, isto é, uma teoria que possa fornecer-nos as razões do método superando o plano puramente metodológico. Uma das primeiras exigências da arqueologia é a proibição 
de estender-se mais além das positividades. Outra, é a de descrever as regras de formação que são condições de possibilidade dessas positividades. O arqueólogo se propõe realizar uma descrição empírica. Não obstante, analisa as condições de existência às quais, portanto, são tanto históricas, quanto, ao mesmo tempo, transcendentais. Eis, aqui, o duplo empírico transcendental que aprisiona a quem o delatou [...]. A arqueologia busca tornar explícito o impensado - o pensamento anônimo - em outra cultura. Se assegura de não analisar seu próprio impensado, mas agrega outra medida de prudência que a sucumbe: evitar a vontade de verdade de sua época. Ora, se não se pode conhecer esta, mal se pode prescindir dela. Ou seja: essa é outra das contradições modernas denunciadas por Foucault: pensar o impensado (MICIELI, 2003, p. 143).

Chegando até aqui, em que pese a tamanha "vontade de transgredir" sem, é claro, consumir-se num "furor de destruir" (situando, pois, Foucault como um pensador "rebelde"), não se pode, todavia, perder de vista que tal "urgência" estava em curso ou, melhor, já se preparava. E isso, por exemplo, no interior da própria fenomenologia do qual Merleau-Ponty, como se sabe, marca uma radical "dissidência": a dissolução do cogito, para além de todo aparato "intencional". É o que, avaliza Deleuze (DELEUZE, 1986, p. 116, 117), a propósito de Le Visible et l'Invisible (1964): "a ruptura de Foucault com a fenomenologia no sentido 'vulgar', isto é, com a intencionalidade [...] é uma ruptura que se opera, até mesmo no interior da fenomenologia, tal como em Heidegger ou Merleau-Ponty, em direção ao ser". Caberia ver então até onde Le Visible et l'Invisible é um dos signos dessa "transgressão", embora Foucault pareça se limitar bem mais a uma leitura dos primeiros trabalhos merleau-pontyanos. Senão, vejamos, brevemente, mais de perto isso.

O fato fundamental é o de que não há como fazer vistas grossas sobre certa influência difusa não apenas de Husserl, mas, sobretudo, do "último" Merleau-Ponty em Foucault. É essa questão que ficara um tanto aberta logo após à conferência de Lebrun (1989), durante as intervenções. A investida merleau-pontyana de borrar a fronteira que separa o transcendental do empírico será, aliás, uma posição seguida à risca por Foucault. Lebrun (1989, p. 44), mais uma vez, denota acerca 
do quanto "As Palavras e as Coisas segue corretamente o pensamento de Merleau-Ponty". "Contudo", adverte ele:

[...] é hora de recordar que Foucault não está falando aqui, em seu próprio nome: contenta-se em designar um lugar, em seu mapa arqueológico, à "Finitude moderna" - e, muitas vezes, dá a palavra a MerleauPonty, esse incansável crítico do "pensamento que sobrevoa". Como poderia o pensamento, perguntava Merleau-Ponty, elidir o seu enraizamento no corpo, na linguagem, na infância? A menos que vá viver em Sirius, ele terá de reconhecer que "o espírito é o outro lado do corpo", que "o mundo sensível é mais velho que o universo do pensamento". Esse tema Foucault retoma quando vai descrever o "Cogito moderno" (LEBRUN, 2006, p. 344) ${ }^{10}$.

É fato ainda que, no rol de suas críticas à fenomenologia, Foucault assume posições discutíveis ao situar, indiscriminadamente, MerleauPonty nessa escola, incorrendo, pois, em alguns equívocos. É o que deixa entender numa de suas entrevistas:

Na época (do pós-guerra), o eu era compreendido como categoria de fundamento. As determinações inconscientes não podiam ser aceitas [...]. Em nome do humanismo, em nome do eu humano em sua soberania, numerosos fenomenólogos, pelo menos na França, tais como Sartre e Merleau-Ponty, não podiam aceitar a categoria do inconsciente. Só o admitiam como uma espécie de sombra, alguma coisa marginal, um a mais: a consciência não devia perder seus direitos soberanos (FOUCAULT, 2002, p. 343).

"Aqui", sem dúvida, comenta Furlan (2009, p. 106), “Foucault está muito aquém dele mesmo, pois, como se sabe, em As Palavras $e$ as Coisas, ele destaca justamente o descentramento do cogito ou da consciência operado pelas filosofias da finitude, e, assim, falar em soberania do eu representa certamente um exagero". Em tal contexto, se

${ }^{10}$ Canguilhem (2012, p. 28-29), por seu turno, também nota de que "Foucault teve, sem dúvida, o sentimento de não falar somente para si, de não somente indicar o ponto obscuro (ainda que não secreto) a partir do qual se desdobra o discurso conciso e, por vezes, difícil de As Palavras e as Coisas, tendo também o sentimento de indicar a questão que, fora de toda preocupação tradicional, constitui para a filosofia sua tarefa atual". 
de um lado, as divergências entre Foucault e Merleau-Ponty saltam aos olhos (Cf. CHAUÍ, 1980, p. 199-200), de outro, as fronteiras que os separam nem sempre são tão nítidas: há convergências passíveis ou quem sabe até produtivas a serem exploradas. Nessa perspectiva, volta a observar Deleuze (1986, p. 118) "não há dúvida que Foucault encontrou uma forte inspiração teórica em Heidegger, e em Merleau-Ponty, para o tema que o inquietava: a dobra, o forro [...]; a dobra como forro em Foucault vai assumir feição inteiramente nova, embora conservando o seu alcance ontológico" ${ }^{11}$. É nessa direção que, de forma oportuna, dois recentes estudos ensaiam um maior aprofundamento.

O primeiro é o livro de Bimbenet, Après Merleau-Ponty (2011) no qual o autor situa Merleau-Ponty e Foucault em seus respectivos, mas convergentes, estilos reflexivos. A crítica foucaultiana à fenomenologia é retomada. Adentrar, pois, no domínio do "impensado" poderia nos levar a crer em certa "impotência do pensamento":

Filósofo indefinidamente procrastinador, Merleau-Ponty teria apenas invocado a síntese tão esperada do empírico e do transcendental, ou do saber positivo e da filosofia sem jamais poder produzir outras coisas que duplas negações. É, por exemplo, a definição infeliz que Foucault, ao fim de As Palavras e as Coisas, dá daquilo que ele chama de "análise do vivido" e, por detrás da qual, é difícil não perceber a estatura do próprio Merleau-Ponty (BIMBENET, 2011, p. 9).

Qual o problema de tal "análise"? Ela é uma "reflexão de nível mista" (FOUCAULT, 1966, p. 352). A questão é que "nessa Dobra a filosofia adormeceu num sono novo; não mais o do Dogmatismo, mas o da Antropologia" (Idem, 1966, p. 352). Por isso, algo "que se pretende ao mesmo tempo empírico e crítico só pode ser, a um tempo, positivista e escatológico; o homem aí aparece como uma verdade ao mesmo tempo reduzida e prometida. A ingenuidade pré-crítica nele reina

11 Aos olhos de Foucault (1966, p. 291), a experiência genuína da vida "funciona como uma ontologia selvagem que busca dizer o ser e o não-ser indissociáveis de todos os seres". Impossível, pois, não reconhecer, nessas linhas, certo traço merleaupontyano. É, todavia, entre 1949 e 1952 que Foucault acompanha os cursos de Merleau-Ponty na Sorbonne, entre esses, "As ciências humanas e a fenomenologia", além da descoberta de Saussure. Sobre o fenomenólogo francês, de maneira reveladora, testemunha Foucault (2002, p. 5): "Ele exercia sobre nós uma fascinação". 
sem restrições" (Idem, 1966, p. 331). Um humanismo fenomenológico como o de Merleau-Ponty incidiria, aqui, em seu limite último: trata-se, enfim, de um programa malogrado, dormente. Merleau-Ponty seria mais uma vítima da ilusão retrospectiva antropológica; ilusão perdida. Disso resulta o modo peculiar como Foucault estigmatiza o caráter oscilante da dublagem (empírico-transcendental).

Ora, a obra de Merleau-Ponty se projeta longe, bem longe, desse pretendido diagnóstico. Não se trata de nenhuma concessão positivista ou escatológica. Afinal, se Merleau-Ponty (DOSTOIÉVSKI, 2000, p. 13) quer pensar um "meio comum entre a filosofia e o saber positivo [...] uma terceira dimensão onde nossa passividade e nossa atividade, nossa autonomia e nossa dependência, cessariam de ser contraditórias" é porque há uma nova ideia de razão em jogo: "A tarefa é, pois, alargar nossa razão para torná-la capaz de compreender aquilo que em nós e nos outros precede e excede a razão" (MERLEAU-PONTY, 1960, p. 154). Essa tarefa de nosso século é a que escava sob a superfície do pensamento o seu "impensado" como horizonte mais amplo e aberto. É este que dá vida ao conceito abrindo-o ainda mais, sem, no entanto, destruí-lo. Assim, diferentemente de Foucault não há que escolher entre o empírico e o transcendental. Para além de uma "má-ambiguidade", é preciso desvelar uma "boa ambiguidade", isto é, aquela que se inscreve noutro movimento: a de uma "dialética sem síntese". Como volta a analisar Bimbenet (2011, p. 19):

Ora, não se ganha grande coisa em querer, a todo preço, a dissolução do sujeito ou do homem, da razão ou de outra instância fundadora [...]. Uma tal apelação é muito conveniente em sua boa vontade radicalista para dizer o que quer que seja de interessante. Ela nos impede de perceber o que é que está em jogo no gesto de Foucault: não o fim do homem enquanto tal, ou da razão enquanto tal, mas, antes, o fim de uma certa ideia, historicamente constituída, portanto, particular, constrangedora, do homem e da razão. O nietzschianismo de Foucault, em As Palavras $e$ as Coisas, toma por alvos, ídolos filosóficos acusados menos de serem falsos ou ilusórios em seu conteúdo (metafísico, racionalista, idealista, etc.), mas mais de serem um obstáculo para o pensamento, para sua abertura e sua liberdade. [...]. Compreendamos bem: a morte do homem é um gesto "crítico" que desloca os limites do pensamento e lhe abre um 
novo domínio de exploração. Ela alarga a razão, antes que ela apenas se desfaça. Nesse sentido, ela participa do projeto emancipador moderno anunciado pela Aufklärung ${ }^{12}$.

O aspecto relevante é que essa nova ideia de razão meditada programaticamente por Merleau-Ponty é retomada por Foucault em vários momentos de sua obra. Novamente, observa Bimbenet (2011, p. 21): “Desse ponto de vista, bem poderiam Merleau-Ponty e Foucault estar mais próximos do que deixa entender o nietzschianismo de $A s$ Palavras e as Coisas. Um e outro trabalham numa descompartimentação da razão que é tudo, exceto um efeito de anúncio". Não há dúvida, obviamente, que há diferença entre ambos: "Em nenhum momento o ethos filosófico de que fala Foucault pretendeu ser outra coisa que um ethos; jamais ele pretendeu requerer as condições de possibilidade no ser [...]. O que Foucault deseja como um bem, Merleau-Ponty, ao contrário, descreve fenomenologicamente como fazendo parte daquilo que nós somos" (BIMBENET, 2011, p. 26). Há um estilo ou uma maneira de pensar em que se aproximam, isto é, "parece se exprimir em um e outro um mesmo 'humor filosófico', uma mesma 'tonalidade de pensamento'” (Idem, 2011, p. 26). Há um exercício do pensamento, um nível de experiência "impensada", "muda", informulada em curso, ou seja, um mesmo elã que fez sempre da fenomenologia esse movimento de inacabamento como uma ordem de inteligibilidade nascente. Sob esse ângulo, "Merleau-Ponty partilha com Foucault, um apetite 'rimbaudiano' pelo novo, um desejo do desconhecido; o que em um se sonha como desaparecimento e abolição de si, em outro, se projeta ontologicamente como o nascimento continuado de um sentido imprevisível" (Idem, 2011, p. 40). Motivo pelo qual, "com eles se anteveem todas novas maneiras de pensar o homem e seu devir humano, e, portanto, quer-se ou não, uma 'nova ideia da razão'. Das transgressões inéditas, espera-se limites a serem atravessados, territórios a serem explorados. O impensado não é o que desfaz o pensamento, mas àquilo ao qual ele aspira, por sua renovação" (Idem, 2011, p. 42).

12 Cf. Foucault $(2000$, p. 345). 
É desde um prisma não tão distante que se projeta um segundo trabalho, qual seja, o livro de Judith Revel Foucault avec Merleau-Ponty (2015) em que é trazido para o primeiro plano, a questão política imersa no sentido da história e do presente. A autora discute, conjuntamente, tanto a obra de Foucault quanto a de Merleau-Ponty costurando nestas alianças implícitas. Vejamos o problema da história: para Foucault, os limites da história e da filosofia não se situam nem completamente dentro, nem inteiramente fora, mas entre ambos, já que "a filosofia é um gesto novo que consiste em interrogar as condições históricas de nossas maneiras de dizer, de ver e de agir no mundo" (REVEL, 2015, p. 8). Haveria, portanto, "uma dobra na história que se joga sobre si mesma: nada lhe é estranho; tudo está imerso e produz" (Idem, 2015, p. 109). Merleau-Ponty, a sua vez, entrevê um "quiasma da história". Por quiasma é preciso entender a possibilidade de "pensar as polaridades opostas em conjunto" (Idem, 2015, p. 182) e não por meio de um modelo que, artificialmente, as dissociaria. O quiasma é um dispositivo em cruz: reúne sobre uma simetria que instala um movimento de ir e vir entre os polos. Ele revela a estrutura perceptiva de nossa relação com o mundo, abaixo de todo juízo ou de toda operação tética, imprimindo um movimento de co-implicação, de reversibilidade ontológica pela qual a história se compreende.

Para Foucault, trata-se de viver na história e não apenas pensá-la, uma vez que "a vida é uma diferença criadora sem fim e o ser não é outra coisa que esse processo imanente, absolutamente material, de diferenciação de si" (REVEL, 2015, p. 76). E isso pela simples razão de que a vida não tem começo nem fim, permanecendo, indefinidamente, aberta. Já, em Merleau-Ponty, como em Marx, há que descer a filosofia do céu para a terra, confrontando-se com os problemas que são seus na vida cotidiana. Nesse contexto, a ação política se define como diferença produtiva. O que isso significa? Significa que, numa linha diametralmente diversa de Sartre ou do marxismo ortodoxo da época, a vida é como uma matriz criativa, já que a história não caminha em linha reta. A história é, causalmente, irredutível: é irrupção da novidade no interior de um campo. Assim, malgrado se sirvam de conceitos e argumentos distintos, Merleau-Ponty e Foucault têm em 
comum o gesto de libertar a historicidade do pressuposto teleológico, isto é, de interrogá-la fora da alternativa abstrata entre determinismo e liberdade inscrevendo a possibilidade de transformação no coração do presente. A ontologia foucaultiana que introduz uma "diferença" na história é uma "ontologia negativa" no sentido merleau-pontyano em que se compreende a negatividade como matriz produtora.

O que esses breves colóquios demarcam, é, pelo menos, um agenciamento mútuo em que tanto Foucault quanto Merleau-Ponty podem comparecer produtivamente. A boa nova trazida por As Palavras e as Coisas, como um gesto de subversão ou de desconstrução, consiste, nas palavras de Canguilhem (2012, p. 15), em abrir "um campo epistemológico sem precedentes"; campo este que Foucault não decripta, mas explora. Embora num registro diverso da fenomenologia, a arqueologia não perde de vista um alcance decisivo que Husserl já teria inscrito como intenção de princípio: o retorno às coisas mesmas. Esse recuo, Foucault fará, ao seu modo, é claro, até porque sua obra, uma vez revisitada, circunscreve uma zona de sombra própria, abrindo-nos a um "impensado" ou lançando-nos a uma "terceira margem"13. É esse, talvez, o marco decisivo que o livro de 1966 deixa aos seus leitores de maneira desconcertante.

\section{Referências}

BIMBENET, E. Après Merleau-Ponty: études sur la fécondité d'une pensée. Paris: Vrin, 2011.

CANGUILHEM, G. Michel Foucault: morte do homem ou esgotamento do cogito? Trad. Fábio Ferreira de Almeida. Goiânia: Edições Ricochete, 2012.

CASTILHO, F. Husserl e a via redutiva da pergunta-recorrente que parte da Lebenswelt. Campinas, SP: Edunicamp, 2015.

13 Para parodiar, aqui, o espírito de homenagem prestada por Merleau-Ponty a Husserl, reportado por Sílvio Gallo (2014, p. 15) em seu "Editorial": trata-se também, no caso de Foucault, de "pensar e problematizar aquilo que ele não pensou, ou o fez apenas de forma marginal". 
CHAUÍ, M. S. “Notas". In: Textos escolhidos (Volume Merleau-Ponty). São Paulo: Abril Cultural, 1980 (Coleção Os Pensadores).

CHAUÍ, M. S. Experiência do pensamento: ensaios sobre a obra de MerleauPonty. São Paulo: Martins Fontes, 2002 (Coleção Tópicos).

DELEUZE, G. Foucault. Paris: Minuit, 1986.

DOSTOIÉVSKI, F. Memórias do subsolo. Trad. Boris Schnaiderman. 3. ed. São Paulo: Editora 34, 2000.

DREYFUS, H. L.; RABINOW, P. Michel Foucault, uma trajetória filosófica: para além do estruturalismo e da hermenêutica. Trad. Vera Porto Carrero. Rio de Janeiro: Forense Universitária, 1995.

FOUCAULT, M. Les mots et les choses: une archéologie des sciences humaines. Paris: Gallimard, 1966.

FOUCAULT, M. “O que são as Luzes?". In: Ditos e escritos II: arqueologia das ciências e história dos sistemas de pensamento. Rio de Janeiro: Forense Universitária, 2000. p. 335-351.

FOUCAULT, M. “Problematização do sujeito: psicologia, psiquiatria e psicanálise". In: Ditos e escritos (I). 2. ed. Trad. Vera Lucia Avellar Ribeiro. Rio de Janeiro: Forense Universitária, 2002.

FREUD, S. "O inconsciente". In: Obras Completas (XII). Trad. Paulo Cézar de Souza. São Paulo: Companhia das Letras, 2010.

FURLAN, R. "São pertinentes as críticas de Foucault às filosofias da finitude, particularmente a Sartre e Merleau-Ponty?". In: CARNEIRO, M. C. \& GENTIL, H. S. (Org.). Filosofia francesa contemporânea. São Paulo: Cultura Acadêmica/ Fundação Editora UNESP, 2009. p. 104-119.

GALLO, S. “O 'efeito Foucault' em Educação”. In: Pro-Posições, v. 25, n. 2 (74), p. 15-21, maio/ago. 2014.

HEIDEGGER, M. "Der Satz vom Grund". In: Abteilung: Veröffentlichte Schriften 1910-1976. GA 10. 2. ed. Frankfurt am Main: Vittorio Klostermann, 1997.

HUGO, V. Les misérables. Paris: GF, 1993. 
HUSSERL, E. Ideias para uma fenomenologia pura e para uma filosofia fenomenológica: introdução geral à fenomenologia pura. Trad. Márcio Suzuki. Aparecida (SP): Idéias \& Letras, 2006.

HUSSERL, E. A crise das ciências europeias e a fenomenologia transcendental: uma introdução à filosofia fenomenológica. Trad. Diogo Falcão Ferrer. Lisboa: Centro de Filosofia Universitas Olisiponensis, 2008. (Phainomenon Clássicos de Fenomenologia).

LEBRUN, G. "Note sur la phénoménologie dans Les mots et les choses". In: VVAA, Michel Foucault philosophe. Paris: Seuil, 1989. p. 33-53.

LEBRUN, G. “Transgredir a finitude”. In: (MOURA, C. A. R. et alii, Orgs.). A filosofia e sua história. São Paulo: Cosac Naify, 2006. p. 341-354.

MERLEAU-PONTY, M. Signes. Paris: Gallimard, 1960.

MERLEAU-PONTY, M. Le visible et l'invisible. Paris: Gallimard, 1964.

MERLEAU-PONTY, M. La nature. Paris: Seuil, 1995.

MERLEAU-PONTY, M. Sens et non-sens. Paris: Gallimard, 1996.

MERLEAU-PONTY, M. Parcours deux (1951-1961). Lagrasse: Verdier, 2000.

MERLEAU-PONTY, M. “Apresentação da candidatura de Claude Lévi-Strauss à cadeira de Antropologia Social". Trad. Paulo Neves. In: Estudos Avançados 23 (67), 2009. p. 217-222.

MICIELI, C. Foucault y la fenomenología: Kant, Husserl, Merleau-Ponty. Prólogo de Roberto J. Walton. Buenos Aires: Biblos, 2003.

NALLI, M. A. G. Foucault e a fenomenologia. São Paulo: Loyola, 2006.

PANZERI, D. Fútbol: la dinámica de lo impensado. Madrid: Capitán Swing, 2011.

PRADO JR, B. “Os limites da Aufklärung”. In: Estudos CEBRAP, São Paulo, v. 15,1976 . p. $168-173$.

PRADO JR, B. Erro, ilusão e loucura: ensaios. São Paulo: Editora 34, 2004. 
REVEL, J. Foucault avec Merleau-Ponty: ontologie politique, présentisme et histoire. Paris: Vrin, 2015.

SILVA, C. A. F. A natureza primordial: Merleau-Ponty e o 'logos do mundo estético'. Cascavel (PR): Edunioeste, 2010.

SILVA, C. A. F. “O retorno ao mundo da vida: Merleau-Ponty, leitor de Husserl”. In: Revista Filosófica de Coimbra, v. 21, 2012. p. 11-32.

WHITEHEAD, A. N. The concept of nature. New York: Dover Publications, 2004.

Recebido: 20/09/2016

Received: 09/20/2016

Aprovado: 30/10/2016

Approved: 10/30/2016 